УДК 581.4:631.52:633.522

(C) 2013

Конопля К. В., кандидат сільськогосподарських наук

Глухівський національний педагогічний університет ім. Олександра Довженка

\title{
ЕНЕРГІЯ ПРОРОСТАННЯ І СХОЖІСТЬ НАСІННЯ КОНОПЕЛЬ РІЗНОЇ КРУПНОСТІ
}

\section{Рецензент - кандидат сільськогосподарських наук С. В. Міщенко}

\begin{abstract}
Досліджено насіння 14 сортів конопель за енертією проростання і схожістю: 1) індивідуальних рослин з найбільшою, середньою і найменшою масою 1000 насінин; 2) популяції крупної, середньої та дрібної фракиій. В обох дослідах аналізували виключно нормально стигле насіння незалежно від фракиії його, виключаючи фактор негативного впливу недозрілого насіння. Виявлено, щзо всі фракції насіння індивідуальних рослин і популячії дають високі показники як за енертією проростання, так $i$ за сходами. Факт установлення того, щзо стигле насіння дрібної фракиії конопель за життєздатністю не поступається насінню крупної і середньої фракиій, свідчить про його повноиінність як посівного матеріалу.
\end{abstract}

Ключові слова: коноплі, насіння, маса 1000 насінин, крупна, середня і дрібна фракиіі насіння, енеріія проростання насіння, схожість насіння.

Постановка проблеми. Селекційне дослідження крупності насіння конопель $[1,3]$ тісно пов'язане 3 вивченням життєздатності його, зокрема 3 необхідністю встановлення параметрів енергії проростання і сходів посівного матеріалу в лабораторних умовах.

Аналіз останніх досліджень і публікацій, у яких започатковано розв'язання проблеми. Вивченням подібного питання займалися С. И. Плотников [4] і А. П. Демкин [2]. Дослідження проводились у напрямі встановлення залежності схожості насіння конопель від забарвлення оболонки i крупності. Залучавши до експериментів насіння різної стиглості, не виключаючи «зеленець», існувала думка, що дрібне насіння не є якісним посівним матеріалом.

Нами були залучені до дослідження сучасні сорти конопель різного географічного походження 3 метою встановлення параметрів життєздатності нормально стиглого насіння різних фракцій конопель для практичного використання в селекції.

Для виконання мети ставилися наступні завдання:

- виявити параметри енергїі проростання і сходів насіння індивідуальних рослин із найбільшою, середньою і найменшою масою 1000 насінин;

- дослідити параметри енергії проростання і схо- дів популяції насіння крупної, середньої та дрібної фракцій.

Матеріали і методи досліджень. До вивчення нами було залучено 14 сортів конопель різного походження, зокрема Єрмаківські місцеві, Глухівські 10, ЮС-9 - сорти дводомних конопель, Fedora 17 i Futura 75 - французькі гібриди, одержані в результаті схрещування дводомних конопель $з$ однодомними, решта (Глухівські 18, Глухівські 33, Глухівські 57, Глухівські 58, ЮСО-14, ЮСО-31, Золотоніські 11, Золотоніські 15, Синельниківські 3) сорти однодомних конопель. Коноплі вирощували в оціночному розсаднику, площа живлення 50x5 см. У період стиглості конопель відбирали по 30 рослин кожного сорту, індивідуально вручну обмолочували насіння.

Експерименти проводили в 2003-2004 роках на дослідному полі та в лабораторії Інституту луб'яних культур УААН.

Результати досліджень. Пророщування насіння різної крупності здійснювалося нами за такою методикою: в одному досліді по кожному із 14 сортів для пророщування насіння відбирали індивідуальні рослини 3 найбільшою, середньою і найменшою масою 1000 насінин. В іншому експерименті по кожному сорту брали популяцію насіння й розподіляли його за допомогою спеціальних сит на крупну, середню та дрібну фракції. Щоб виключити фактор негативного впливу недозрілого насіння («зеленцю»), в обох дослідах аналізували тільки нормально стигле насіння, незалежно від його фракції. 3 даних таблиці видно, що всі фракції насіння дають високі показники як за енергією проростання, так і за сходами. Розходження на достовірному рівні відмічено лише за енергією проростання насіння індивідуальних рослин між крупним і середнім та крупним і дрібним насінням $(\mathrm{P}<0,05)$. Цей факт пояснюється тим, що більші за розміром насінини, проростаючи, набухають повільніше, ніж менші за величиною насінини. В інших варіантах досліду різниця досить незначна, недостовірна. Між даними аналізу насіння індивідуальних рослин і популяції принципових відмінностей не виявлено. 
Енергія проростання і схожість насіння конопель різної крупності (середнє, 14 сортів)

\begin{tabular}{|c|c|c|c|c|c|c|c|}
\hline \multirow{2}{*}{$\begin{array}{l}\text { Фракція } \\
\text { насіння }\end{array}$} & \multirow{2}{*}{$\begin{array}{c}\text { Загальна } \\
\text { кількість } \\
\text { насінин, шт. }\end{array}$} & \multicolumn{3}{|c|}{ Енерггія проростання насіння } & \multicolumn{3}{|c|}{ Схожість насіння } \\
\hline & & 日 $\pm \mathrm{S}^{\text {日 }}, \%$ & $\mathrm{~V}, \%$ & ліміти, \% & 日 $\pm \mathrm{S}^{\text {母 }}, \%$ & $\mathrm{~V}, \%$ & ліміти, \% \\
\hline \multicolumn{8}{|c|}{ Насіння індивідуальних рослин сорту } \\
\hline Крупна (к) & 1400 & $93,64 \pm 1,89$ & 7,56 & $76-99$ & $98,79 \pm 0,38$ & 1,44 & $95-100$ \\
\hline Середня (c) & 1400 & $98,50 \pm 0,39$ & 1,48 & $96-100$ & $99,43 \pm 0,20$ & 0,76 & $98-100$ \\
\hline Дрібна (д) & 1400 & $97,93 \pm 0,58$ & 2,21 & $92-100$ & $99,21 \pm 0,21$ & 0,81 & $98-100$ \\
\hline & & $\mathrm{P}_{\mathrm{K}}-\mathrm{P}_{\mathrm{c}}<0,05$ & & & & & \\
\hline & & $\mathrm{P}_{\mathrm{K}}-\mathrm{P}_{\mathrm{M}}<0,05$ & & & & & \\
\hline \multicolumn{8}{|c|}{ Популяція насіння сорту } \\
\hline Крупна (к) & 1400 & $97,43 \pm 0,62$ & 2,37 & $94-100$ & $98,21 \pm 0,37$ & 1,39 & $95-100$ \\
\hline Середня (c) & 1400 & $98,21 \pm 0,72$ & 2,74 & $95-100$ & $98,93 \pm 0,44$ & 1,66 & $95-100$ \\
\hline Дрібна (д) & 1400 & $98,50 \pm 0,65$ & 2,48 & $91-100$ & $99,00 \pm 0,43$ & 1,63 & $94-100$ \\
\hline
\end{tabular}

Слід зазначити високий рівень проростання насіння конопель: у межах сортів енергія проростання його становить 76-100\%, а схожість 94-100 \%. Достигле насіння конопель усіх фракцій є високоякісним посівним матеріалом.

Факт установлення того, що стигле насіння дрібної фракції конопель за життєздатністю

\section{БІБЛІОГРАФІЯ}

1. Вакуленко К. В. Маса 1000 насінин конопель як фактор насіннєвої продуктивності / $K . B . B a-$ куленко // Наукова спадщина академіка М. М. Гришка : матеріали всеукраїнської науково-практичної конференції, присвяченої пам'яті М. М. Гришка - видатного селекціонера, генетика, ботаніка та громадського діяча, 12-13 квітня 2005 р. - Глухів : РВВ Глухівського державного педагогічного університету, 2005. - С. 147-149. 2. Демкин А. П. Семена и подготовка их к посеву / (енергією проростання і схожістю) не поступається насінню крупної та середньої фракцій, свідчить про його повноцінність як посівного матеріалу.

Висновок. Дрібне насіння (але стигле) не поступається за енергією проростання і повною схожістю крупному й середньому.

А. П. Демкин // Конопля. - М. : Сельхозгиз, 1938. C. 291-345.

3. Мигаль М. Д. Про деякі біологічні фактори насіннєвої продуктивності конопель / М. Д. Мигаль, К. В. Вакуленко // Вісник Сумського національного аграрного університету. - Суми, 2004. № 6 (9). - С. 29-33.

4. Плотников С. И. Конопля / С. И. Плотников. М.- Л. : ОГИЗ, 1931. - 304 c. 